\title{
Grand Challenges in Waste Management in Agroecosystems
}

\author{
Maria Pilar Bernal* \\ Centro de Edafología y Biología Aplicada del Segura, Consejo Superior de Investigaciones Científicas (CSIC), \\ Murcia, Spain
}

Keywords: soil fertility, nutrient availability, emerging contaminants, treatment technologies, gaseous emissions, soil microbial diversity, soil function

The identification of the key challenges in waste management in agroecosystems is difficult due to the interdisciplinary character of the topic (soil science, agronomy, microbiology, plant physiology, environment, ecology, technology engineering, etc.), which gives rise to different points of view and priorities.

The interest in and importance of waste management resulted from the concentration of the population in cities following migration from rural areas, industrial development, and the separation of livestock farming from crops, all of which led to accumulation of wastes which needed to be dealt with. The impact of fertilization by inorganic compounds and of organic fertilization with farmyard manure (FYM) on crop yield was first studied in the oldest, continuous agronomic experiments in the world that started between 1843 and 1856 by Sir John Bennet Lawes and Sir Joseph Henry Gilbert in the UK. Such experiments considered different agronomic aspects such as crop rotation, soil texture, and soil pH, in addition to organic (mainly FYM and rape cake) and inorganic fertilization, for different crops in the "Classical" Rothamsted experiments (http://www.rothamsted.ac.uk). Later, these experiments were expanded to include other organic materials-such as straw, peat, green manures, compost, or sewage sludge-in distinct long-term experiments established at Rothamsted and Woburn farms in the twentieth century (http://www.rothamsted.ac.uk). Not only the nutrient supply by the organic wastes was evaluated but also the importance of organic fertilization for maintaining or improving soil organic matter (OM), microbial biomass, and enzymatic activity was revealed, as well as negative effects on soils related to heavy metals from sewage sludge.

Nowadays, the intensive agriculture systems for both livestock and crop production generate huge amount of manure in concentrated areas, which necessitates both on-farm and off-farm management as they cannot be applied entirely to crops. Also, the development of new industries, processes, and materials has increased the variety of organic wastes to be treated. All these require new treatment technologies adapted to these new wastes and accumulations. In fact, the waste policy in modern society is aimed at minimizing the negative effects of the waste generation on human health and the environment. The old linear system of an economy based on a take-make-consume and dispose pattern is converting into a circular system, where the connection between resource use and waste residuals is being made. The ideas of the Circular Economy (EC, 2014) and Bioeconomy Strategy (EC, 2012) are developing in Europe, promoting the sustainable and integrated use of biological resources and wastes for the production of food, energy, and bio-based products. These imply the establishment of new ways of turning waste into a resource and new models of consumer behavior.

Great pressure is being placed on the scientific community to provide answers to the questions arising for these new concepts of Circular Economy and Bioeconomy: development of treatment technologies, enhancement of environmental conservation and sustainability, and ensuring food safety. The grand challenges in waste management in agroecosystems are to provide solutions to problems related to the following:

- Nutrient availability ( $\mathrm{N}$ and $\mathrm{P}$ ) from organic wastes: fertilizer efficiency and soil nutrient cycles for efficient substitution of mineral fertilizers.

- Treatment technologies for waste re-use: recovery of nutrients and valuable compounds (biorefinery), anaerobic digestion, and composting to obtain quality products. 
- The presence of pollutants or hazardous compounds in organic wastes: bioavailability, toxicity, soil risk assessment, and biological transformation during waste treatment processes for food safety.

- The environmental implications of gaseous emissionsammonia $\left(\mathrm{NH}_{3}\right)$, greenhouse gases (GHGs), bioaerosols, particulate matter, odors, etc. - and their mitigation.

- Implication of organic wastes for soil C conservation, microbial diversity, and function.

Agriculture is heavily dependent on synthetic fertilizers $(\mathrm{N}$ and $\mathrm{P}$ ) and their provision results in large environmental impacts at local, regional, and global scales. Therefore, the substitution of nutrients from synthetic mineral fertilizer by waste derived products is a current need. However, the determination of the fertilizer efficiency of organic materials is a challenge since it depends on mineralization-immobilization cycles, dissolution and absorption processes, and pathways of losses from the soil systems (gaseous emissions, surface runoff or leaching; Burton and Turner, 2003; Sommer et al., 2013). Therefore, there is a need for information concerning the plant nutrient availability of certain products (mainly composts and digestates), as frequently only total concentrations are indicated (Alburquerque et al., 2012; Bernal et al., 2017).

New processes for the recovery of nutrients and valuable compounds from organic wastes are under development. The recovery of $\mathrm{P}$ by precipitation or struvite formation (Martí et al., 2010; Szogi et al., 2015) and recovery of ammonia from wastes by stripping or using gas-permeable membranes (Serna-Maza et al., 2015; Vanotti et al., 2017) to obtain marketable fertilizers are novel processes for animal manure/slurry and sewage sludge treatment that should be developed industrially. In addition, the quality of the products must be guaranteed for their proper marketing.

The use of organic wastes in agricultural soils may ensure not only high yields but also quality and healthy food, the prevention of pollution, and the maintenance of sustainable soils and ecosystems. Among the major environmental impacts concerning waste management in soil-plant systems is the contamination of soil and water by nutrients, organic carbon, heavy metals, pathogens, and different organic contaminants (Burton and Turner, 2003). Wastewater, sewage sludge, and livestock manures are possible media for the entrance of pharmaceutical compounds and veterinary products (hormones, antibiotics, etc.) into agroecosystems (Hu et al., 2010). Biosolids (high quality, stabilized sewage sludges) are commonly used to improve the soil nutrient content for crop growth in agriculture; in addition, their OM improves soil fertility. However, many pharmaceutical and personal care products, endocrine-disrupting compounds and other emerging contaminants have been detected in the discharge from wastewater treatment plants, indicating their presence in biosolids (Sabourin et al., 2012; Mohapatra et al., 2016), which can be concentrated in crops when using wastewater for irrigation (Calderón-Preciado et al., 2011). Recently, special attention has been paid to studying the efficiency of different waste treatments (composting and anaerobic digestion) for the degradation of veterinary antibiotics and pharmaceuticals (Carballa et al., 2007; Ho et al., 2013; Mitchell et al., 2015; Wang et al., 2015; Butkovskyi et al., 2016). But a deeper knowledge about the transformation of organic pollutants during anaerobic digestion and composting is needed to ensure both the quality and safety of digestates and composts for the commercial market and acceptance by the users (Bernal et al., 2017).

Persistent organic pollutants (POPs), including the polybrominated diphenyl ethers and the polycyclic aromatic hydrocarbons (PAHs), generally have poor water solubility, do not degrade readily in the environment, bioaccumulate in food chains, and have been linked to adverse health effects in both humans and wildlife. The accumulation of POPs in the sludge can occur, and biodegradation has been found in activated sludge (Katsoyiannis and Samara, 2005). The PAHs are the main classes of contaminants of environmental concern, considered toxic and persistent (Haritash and Kaushik, 2009), 16 of them being classified as priority pollutants by the USEPA. The rate of $\mathrm{PAH}_{16}$ biodegradation depends on the $\mathrm{pH}$, temperature, oxygen, microbial population, degree of acclimation, accessibility of nutrients, chemical structure of the compound, cellular transport properties, and chemical partitioning in the growth medium (Haritash and Kaushik, 2009). However, their degradation process in the soil is complex and not fully understood (Serrano et al., 2009). Therefore, the land use of municipal biosolids may have a bioaccumulation and magnification effect on emerging and persistent contaminants, affecting the equilibrium of biological systems from individuals to entire ecosystems. For $\mathrm{PAH}_{16}$ in compost and digestate, a limit of $6 \mathrm{mg} / \mathrm{kg}$ dry matter in the EU has been proposed (Saveyn and Eder, 2014). The persistence in soils and during aerobic (composting) or anaerobic treatments of such specific contaminants, their degradation pathways, and their effects on crop production and quality represent another challenge for researchers. Therefore, the adoption of monitoring protocols and the constant innovation of treatment techniques are the key for future safe fertilization using biosolids and manures.

Management of organic waste has been identified as a major source of anthropogenic emissions contributing to regional (eutrophication, acidification) and global scale (climate change) environmental issues. The microbial degradation of organic- $\mathrm{C}$ compounds present in wastes is responsible for the $\mathrm{N}_{2} \mathrm{O}$ and $\mathrm{CH}_{4}$ production and emissions. Chadwick et al. (2011) reviewed the GHGs emissions from livestock (animal houses, manure storage and treatment, and land spreading) using a whole-system approach (a mass balance). Cattle are considered a key contributor to GHGs emissions, in relation to both the $\mathrm{CH}_{4}$ emitted from enteric fermentation and manure management (VanderZaag et al., 2011). For effective mitigation of the gaseous emissions from solid waste, actions should be taken at all levels of the system, from the animal feed and manure management at the farm to storage and treatment systems (such as anaerobic digestion, biofiltration, and composting) and soil application (Chadwick et al., 2011; Gerber et al., 2013; Pardo et al., 2015; Bernal et al., 2017). The feeding strategy is being considered the key strategy for mitigation of GHGs (Chadwick et al., 2011). However, the variability of the results found, due to the different manure characteristics, climatic environments, soil types, and agronomic and farming conditions, make modeling a necessary tool in order to obtain a true estimate for a variety of situations and climatic conditions, 
especially in warmer climates (Petersen et al., 2013). Controversy exists concerning the present emission factors used for calculating GHG emissions according to the Intergovernmental Panel on Climate Change (IPCC, 2013) and the values may be refined in the future (Pardo et al., 2015).

The GHG emissions from wastewater and sewage sludge treatment plants depend on several processes (thickening, anaerobic digestion, dewatering, incineration, and melting), and high $\mathrm{CH}_{4}$ and $\mathrm{N}_{2} \mathrm{O}$ emissions occur from sludge cake at the landfill site (Soda et al., 2010). Some studies have been carried out on stabilization techniques (liming, anaerobic digestion, and composting), and the use of additives to mitigate the emissions from sewage sludge (Yoshida et al., 2015; Wang et al., 2017). The stabilization processes tend to reduce both $\mathrm{CH}_{4}$ and $\mathrm{N}_{2} \mathrm{O}$ emissions from soils, in comparison with the use of the raw or dewatered sewage sludge.

For soil waste management practices to be sustainable, their environmental impact associated with climate change (GHGs) and ecosystems acidification (ammonia: $\mathrm{NH}_{3}$ ) should be minimized. So, mitigation options should be tested, evaluated, and implemented across climatic zones for the agro-industrial sectors implicated: not only livestock production systems, but also other sectors such as wastewater treatment and sewage sludge management.

The impact of the use of organic wastes on the soil ecosystem remains unclear. Positive effects are associated with the OM provided by the waste materials, which increases the humus content of the soil and the activity and diversity of soil microbial populations. But a negative impact on soil microorganisms can result from the presence of contaminants (organics and heavy metals). The impact of biosolids application on soil microbiota has been extensively studied in short-term experiments. But, the long-term disposal of biosolids can affect negatively the

\section{REFERENCES}

Alburquerque, J. A., de la Fuente, C., Ferrer-Costa, A., Carrasco, L., Cegarra, J., Abad, M., et al. (2012). Assessment of the fertiliser potential of digestates from farm and agroindustrial residues. Biomass Bioenergy 40, 181-189. doi:10.1016/ j.biombioe.2012.02.018

Bernal, M. P., Sommer, S. G., Chadwick, D., Qing, C., Guoxue, L., and Michel, F. C. Jr. (2017). Current approaches and future trends in compost quality criteria for agronomic, environmental, and human health benefits. Adv. Agron. 144, 143-233. doi:10.1016/bs.agron.2017.03.002

Burton, C. H., and Turner, C. (2003). Manure Management: Treatment Strategies for Sustainable Agriculture. Bedford, UK: Silsoe Research Institute, Lister \& Durling Printers.

Butkovskyi, A., Nia, G., Hernandez Leal, L., Rijnaartsa, H. H. M., and Zeeman, G. (2016). Mitigation of micropollutants for black water application in agriculture via composting of anaerobic sludge. J. Hazard. Mater. 303, 41-47. doi:10.1016/ j.jhazmat.2015.10.016

Calderón-Preciado, D., Matamoros, V., and Bayona, J. M. (2011). Occurrence and potential crop uptake of emerging contaminants and related compounds in an agricultural irrigation network. Sci. Total Environ. 412-413, 14-19. doi:10.1016/j.scitotenv.2011.09.057

Carballa, M., Omil, F., Ternes, T., and Lema, J. M. (2007). Fate of pharmaceutical and personal care products (PPCPs) during anaerobic digestion of sewage sludge. Water Res. 41, 2139-2150. doi:10.1016/j.watres.2007.02.012

Chadwick, D., Sommer, S., Thorman, R., Fangueiro, D., Cardenas, L., Amon, B., et al. (2011). Manure management: implications for greenhouse gas emissions. Animal Feed Sci. Technol. 166-167, 514-531. doi:10.1016/j.anifeedsci. 2011.04.036 diversity of soil bacteria and fungi due to heavy metals accumulation (Mossa et al., 2017). The composition of soil microbial communities is sensitive to a variety of land use changes, including agricultural practices such as fertilization, which can cause shifts in the bacterial community resulting in decreased overall diversity and/or disruption of biogeochemical processes, leading to alterations in ecosystem functioning (Coolon et al., 2013). Understanding of the continuous environmental changes and impacts of anthropogenic effects on the environment and climate is vital for future agricultural practices (Santoyo et al., 2017). Currently, it is still poorly understood whether increased soil (microbial) diversity is beneficial for the functioning and sustainability of agricultural systems. A new challenge is to identify the consequences of changes in microbial community structure associated with soil application of wastes, in relation to agroecosystems soil function.

Therefore, five main challenges have been identified in waste management in agroecosystems: to improve nutrient availability and soil cycling; to develop technologies for nutrient re-use; to reduce contaminants and improve food safety; to mitigate environmental emissions; and to enhance soil health and function.

\section{AUTHOR CONTRIBUTIONS}

The author (MPB) has written the paper. No other authors contributed to it.

\section{ACKNOWLEDGMENTS}

This research was funded by the Spanish MINECO through the project CTM2013-48697-C2-1R. The author would like to thank Dr. David J. Walker for the English revision of the manuscript.

Coolon, J. D., Jones, K. L., Todd, T. C., Blair, J. M., and Herman, M. A. (2013). Longterm nitrogen amendment alters the diversity and assemblage of soil bacterial communities in Tallgrass prairie. PLoS ONE 8:e67884. doi:10.1371/journal. pone. 0067884

EC. (2012). "Innovating for sustainable growth: a bioeconomy for Europe," in Communication from the Commission to the European Parliament, the Council, the European Economic and Social Committee and the Committee of The Regions (COM) (Brussels), 60.

EC. (2014). "Towards a circular economy: a zero waste programme for Europe," in Communication from the Commission to the European Parliament, the Council, the European Economic and Social Committee and the Committee of the Regions (COM) Brussels, 398.

Gerber, P. J., Hristov, A. N., Henderson, B., Makkar, H., Oh, J., Lee, C., et al. (2013). Technical options for the mitigation of direct methane and nitrous oxide emissions from livestock: a review. Animal 7, 220-234. doi:10.1017/ S1751731113000876

Haritash, A. K., and Kaushik, C. P. (2009). Biodegradation aspects of polycyclic aromatic hydrocarbons (PAHs): a review. J. Hazard. Mater. 169, 1-15. doi:10.1016/j.jhazmat.2009.03.137

Ho, Y. B., Zakaria, M. P., Latif, P. A., and Saari, N. (2013). Degradation of veterinary antibiotics and hormone during broiler manure composting. Bioresour. Technol. 131, 476-484. doi:10.1016/j.biortech.2012.12.194

$\mathrm{Hu}, \mathrm{X}$., Zhou, Q., and Luo, Y. (2010). Occurrence and source analysis of typical veterinary antibiotics in manure, soil, vegetables and groundwater from organic vegetable bases, northern China. Environ. Pollut. 158, 2992-2998. doi:10.1016/j.envpol.2010.05.023

IPCC. (2013). IPCC Fifth Assessment Report. Climate Change 2013: The Physical Science Basis. Available at: http://www.ipcc.ch/report/ar5/wg1/ 
Katsoyiannis, A., and Samara, C. (2005). Persistent organic pollutants (POPs) in the conventional activated sludge treatment process: fate and mass balance. Environ. Res. 97, 245-257. doi:10.1016/j.envres.2004.09.001

Martí, N., Pastor, L., Bouzas, A., Ferrer, J., and Seco, A. (2010). Phosphorus recovery by struvite crystallization in WWTPs: influence of the sludge treatment line operation. Water Res. 44, 2371-2379. doi:10.1016/j.watres.2009.12.043

Mitchell, S. M., Ullman, J. L., Bary, A., Cogger, C. G., Teel, A. L., and Watts, R. J. (2015). Antibiotic degradation during thermophilic composting. Water Air Soil Pollut. 226, 13. doi:10.1007/s11270-014-2288-Z

Mohapatra, D. P., Cledón, M., Brar, S. K., and Surampalli, R. Y. (2016). Application of wastewater and biosolids in soil: occurrence and fate of emerging contaminants. Water Air Soil Pollut. 227, 77-91. doi:10.1007/s11270-016-2768-4

Mossa, A. W., Dickinson, M. J., West, H. M., Young, S. D., and Crout, N. M. J. (2017). The response of soil microbial diversity and abundance to long-term application of biosolids. Environ. Pollut. 224, 16-25. doi:10.1016/j.envpol. 2017.02.056

Pardo, G., Moral, R., Aguilera, E., and Del Prado, A. (2015). Gaseous emissions from management of solid waste: a systematic review. Global Change Biol. 21, 1313-1327. doi:10.1111/gcb.12806

Petersen, S. O., Blanchard, M., Chadwick, D., Del Prado, A., Eduoard, N., Mosquera, J., et al. (2013). Manure management for greenhouse gas mitigation. Animal 7, 26-282. doi:10.1017/S1751731113000736

Sabourin, L., Duenk, P., Bonte-Gelok, S., Payne, M., Lapen, D. R., and Topp, E. (2012). Uptake of pharmaceuticals, hormones and parabens into vegetables grown in soil fertilized with municipal biosolids. Sci. Total Environ. 431, 233-236. doi:10.1016/j.scitotenv.2012.05.017

Santoyo, G., Hernández-Pacheco, C., Hernandez-Salmerón, J., and HernándezLeón, R. (2017). The role of abiotic factors modulating the plant-microbe-soil interactions: toward sustainable agriculture. A review. Spanish J. Agric. Res. 15, e03R01. doi:10.5424/sjar/2017151-9990

Saveyn, H., and Eder, P. (2014). End-of-Waste Criteria for Biodegradable Waste Subjected to Biological Treatment (Compost \& Digestate): Technical Proposals. Luxembourg: Publications Office of the European Union.

Serna-Maza, A., Heaven, S., and Banks, C. J. (2015). Biogas stripping of ammonia from fresh digestate from a food waste digester. Bioresour. Technol. 190, 66-75. doi:10.1016/j.biortech.2015.04.041

Serrano, I. S., dos Santos, E. C., Menezes, C. R., de Faria, A. F., Franciscon, E., Grossman, M., et al. (2009). Bioremediation of a polyaromatic hydrocarbon contaminated soil by native soil microbiota and bioaugmentation with isolated microbial consortia. Bioresour. Technol. 100, 4669-4675. doi:10.1016/j. biortech.2009.03.079
Soda, S., Iwai, Y., Sei, K., Shimod, Y., and Ike, M. (2010). Model analysis of energy consumption and greenhouse gas emissions of sewage sludge treatment systems with different processes and scales. Water Sci. Technol. 61, 365-373. doi:10.2166/wst.2010.827

Sommer, S. G., Christensen, M. L., Schmidt, T., and Jensen, L. S. (eds) (2013). Animal Manure - Treatment and Management, 1st Edn. Chichester, UK: John Wiley \& Sons, Ltd.

Szogi, A. A., Vanotti, M. B., and Hunt, P. G. (2015). Phosphorus recovery from pig manure prior to land application. J. Environ Manage. 157, 1-7. doi:10.1016/j. jenvman.2015.04.010

VanderZaag, A. C., Jayasundara, S., and Wagner-Riddle, C. (2011). Strategies to mitigate nitrous oxide emissions from land applied manure. Animal Feed Sci. Technol. 166-167, 464-479. doi:10.1016/j.anifeedsci.2011.04.034

Vanotti, M. B., Dube, P. J., Szogi, A. A., and Garcia-Gonzalez, M. C. (2017). Recovery of ammonia and phosphate minerals from swine wastewater using gas-permeable membranes. Water Res. 112, 137-146. doi:10.1016/j.watres.2017.01.045

Wang, J., Ben, W., Zhang, Y., Yang, M., and Qiang, Z. (2015). Effects of thermophilic composting on oxytetracycline, sulfamethazine, and their corresponding resistance genes in swine manure. Environ. Sci. 17, 1654-1660. doi:10.1039/ c5em00132c

Wang, M., Awasthi, M. K., Wang, Q., Chen, H., Ren, X., Zhao, J., et al. (2017). Comparison of additives amendment for mitigation of greenhouse gases and ammonia emission during sewage sludge co-composting based on correlation analysis. Bioresour. Technol. 243, 520-527. doi:10.1016/j.biortech.2017.06.158

Yoshida, H., Nielsen, M. P., Scheutz, C., Jensen, L. S., Christensen, T. H., Nielsen, S., et al. (2015). Effects of sewage sludge stabilization on fertilizer value and greenhouse gas emissions after soil application. Acta Agric. Scand. B Soil Plant Sci. 65, 506-516. doi:10.1080/09064710.2015.1027730

Conflict of Interest Statement: The author declares that the research was conducted in the absence of any commercial or financial relationships that could be construed as a potential conflict of interest.

The reviewer AS and handling editor declared their shared affiliation.

Copyright (C) 2017 Bernal. This is an open-access article distributed under the terms of the Creative Commons Attribution License (CC BY). The use, distribution or reproduction in other forums is permitted, provided the original author(s) or licensor are credited and that the original publication in this journal is cited, in accordance with accepted academic practice. No use, distribution or reproduction is permitted which does not comply with these terms. 